\title{
ON A GENERALIZATION OF A THEOREM OF LEVIN AND STEČKIN AND INEQUALITIES OF THE HERMITE-HADAMARD TYPE
}

\author{
TERESA RAJBA
}

Abstract. We give new necessary and sufficient conditions for higher order convex ordering. These results generalize the Levin-Stečkin theorem (1960) on convex ordering. The obtained results can be useful in the study of the Hermite-Hadamard type inequalities and in particular inequalities between the quadrature operators.

Mathematics subject classification (2010): 26A51, 26D10, 60E15.

Keywords and phrases: Convexity of higher order, $s$-convex order, Hermite-Hadamard type inequality.

\section{REFERENCES}

[1] M. BessenyeI, Hermite-Hadamard-type inequalities for generalized convex functions, J. Inequal. Pure Appl. Math. 9 (2008), 1-51.

[2] M. Bessenyei AND Z. S. PÁles, Higher-order generalizations of Hadamard's inequality, Publ. Math. Debrecen 61 (2002), no. 3-4, 623-643.

[3] M. BesSENYEI AND Z. S. PÁLES, Hadamard-type inequalities for generalized convex functions, Math. Inequal. Appl. 6, 3 (2003), 379-392.

[4] M. Bessenyei AND Z. S. PÁLES, On generalized higher-order convexity and Hermite-Hadamardtype inequalities, Acta Sci. Math. (Szeged), 70 (2004), no. 1-2, 13-24. MR 2005e:26012.

[5] M. BesSENYEI AND Z. S. PÁles, Characterization of higher-order monotonicity via integral inequalities, Proc. R. Soc. Edinburgh Sect. A, 140A, 1 (2010), 723-736.

[6] H. BRASS AND K. PETRAS, Quadrature theory. The theory of numerical integration on a compact interval, Mathematical Surveys and Monographs 178. American Mathematical Society, Providence, RI, 2011.

[7] H. BRASS AND G. SCHMEISSER, Error estimates for interpolatory quadrature formulae, Numer. Math. 37, 3 (1981), 371-386.

[8] M. Denuit, C. LefÈvRE AND M. ShaKed, The s-convex orders among real random variables, with applications, Math. Inequal. Appl., 1 (1998), 585-613.

[9] S. S. Dragomir And C. E. M. Pearce, Selected Topics on Hermite-Hadamard Inequalities and Applications, RGMIA Monographs, Victoria University, 2000, (online: http://rgmia.vu.edu.au/monographs/).

[10] A. Florea, E. PĂLTănea And D. BăLĂ, Convex Ordering Properties and Applications, J. Math. Inequal 9, 4 (2015), 1245-1257.

[11] S. Karlin And A. Novikoff, Generalized convex inequalities, Pacific J. Math. 13, 4 (1963), 12511279.

[12] M. KUCZMA, An Introduction to the Theory of Functional Equations and Inequalities, Prace Naukowe Uniwersytetu Śląskiego w Katowicach, vol. 489, Państwowe Wydawnictwo Naukowe - Uniwersytet Śląski, Warszawa, Kraków, Katowice, 1985.

[13] V. I. Levin And S. B. STEČKIn, Inequalities, Amer. Math. Soc. Transl. 14, 2 (1960), 1-22.

[14] C. P. Niculescu And L. E. Persson, Convex functions and their applications. A contemporary approach, Springer, New York 2006.

[15] A. Olbryś, T. Szostok, Inequalities of the Hermite-Hadamard type involving numerical differentiation formulas, Results. Math., 67 (2015), 403-416. 
[16] J. OHLIN, On a class of measures of dispersion with application to optimal reinsurance, ASTIN Bulletin, 5 (1969), 249-266.

[17] T. Popoviciu, Sur quelques proprietes des fonctions d'une ou de deux variables reelles, Mathematica, 8 (1934), 1-85.

[18] T. RAJBA, On probabilistic characterizations of convexity and delta-convexity, Conference on Inequalities and Applications '14, September 7-13, 2014, Hajdúszoboszló (Hungary).

[19] T. RAJBA, New integral representations of $n$th order convex functions, J. Math. Anal. Appl., 379, 2 (2011), 736-747.

[20] T. RAJBA, On the Ohlin lemma for Hermite-Hadamard-Fejér type inequalities, Math. Inequal. Appl., 17, 2 (2014), 557-571.

[21] T. RAJBA, On strong delta-convexity and Hermite-Hadamard type inequalities for delta-convex functions of higher order, Math. Inequal. Appl., 18, 1 (2015), 267-293.

[22] T. Szostok, Levin Stečkin theorem and inequalities of the Hermite-Hadamard type, arXiv preprint, arXiv: $1411.7708 \mathrm{v} 1$ [math.CA].

[23] T. Szostok, Ohlin's lemma and some inequalities of the Hermite-Hadamard type, Aequationes mathematicae, (2014), 1-12, August 06, 2014.

[24] S. Z. WA̧SOWICZ, Inequalities between the quadrature operators and error bounds of quadrature rules, J. Inequal. Pure Appl. Math., 8, 2 (2007), Article 42, 8 pp.

[25] S. Z. WA̧sowICZ, On quadrature rules, inequalities and error bounds, J. Inequal. Pure Appl. Math. 9, 2 (2008), Article 36, 4 pp.

[26] S. Z. WA̧SOWICZ, A new proof of some inequality connected with quadratures, J. Inequal. Pure Appl. Math., 9, 1 (2008), Article 7, 3 pp.

[27] S. Z. WA̧SOWICZ, On some extremalities in the approximate integration, Math. Inequal. Appl., 13 (2010), 165-174. 